\title{
Research
}

\section{The State of the System and Steps Toward Resilience of Disturbance- dependent Oak Forests}

\author{
$\underline{\text { Tricia G. Knoot }}^{1}, \underline{\text { Lisa A. Schulte }}^{1}, \underline{\text { John C. Tyndall }}^{1}$, and Brian J. Palik ${ }^{2}$
}

\begin{abstract}
Current ecological, economic, and social conditions present unique challenges to natural resource managers seeking to maintain the resilience of disturbance-dependent ecosystems, such as oak (Quercus spp.) forests. Oak-dominated ecosystems throughout the U.S. have historically been perpetuated through periodic disturbance, such as fire, but more recently show decline given shifting disturbance regimes associated with human land management decisions. We characterized the state of the social-ecological oak forest ecosystem in the midwestern U.S. through the perspectives of 32 natural resource professionals. Data from interviews with these change agents provided an integrative understanding of key system components, cross-scale interactions, dependencies, and feedbacks. Foremost, private landowner management decisions figured prominently in influencing oak regeneration success and were directly and indirectly shaped by a suite of interdependent ecological, e.g., deer herbivory, invasive shrub occurrence; economic, e.g., the cost of oak regeneration practices, the stumpage value of maple as compared to oak; and social forces, e.g., forestland parcelization, and personal relationships. Interviewees envisioned, and often preferred, a decline in oak dominance throughout the region, pointing to issues related to general landowner unwillingness to restore oak, the current trajectory of forest change, the threat of forest loss due to parcelization and housing development, and a combination of ecological and social factors that decrease the economic feasibility of restoration efforts. However, a decline in oak dominance may result in ecological communities that have no compositional equivalent on record and may not offer a desirable endpoint. Increasing social support offers the potential to enhance system capacity to manage for oak.
\end{abstract}

Key Words: conservation; oak forests; privately-owned lands; qualitative interviews; resilience; systems analysis

\section{INTRODUCTION}

In many regions of the United States, the present extent and composition of forests are substantially different than during the time period prior to EuroAmerican settlement (Schulte et al. 2007, Nowacki and Abrams 2008), partly because of human land management decisions that have directly and indirectly altered the pattern of disturbance on the landscape. Presettlement disturbance regimes, influenced by a combination of biophysical conditions, ecological processes, and land management decisions by American Indians (Delcourt and Delcourt 1997), created a heterogeneous landscape composed of a variety of forest types of various ages (Abrams 1992, Radeloff et al. 2000, Drever et al. 2006, Schulte et al. 2007). In many regions of the U.S., disturbance-dependent, early- to mid-successional forest types once contributed to landscape heterogeneity, thriving in areas that experienced periodic disturbance, such as fire. More recently, many of these forests have experienced declining regeneration because of more recent land management decisions, e.g., fire suppression, selective harvesting. Examples of such ecosystems include the dry ponderosa pine (Pinus ponderosa) and mixed conifer forests of the Inland Northwest (Hessburg et al. 2005), longleaf pine (Pinus palustris) forests of the Southeast (Platt et al. 1988), mixed-pine ecosystems of the Great Lakes Region (Palik and Pregitzer 1992), and the oak (Quercus spp.)-dominated forests of the eastern and midwestern U.S. (Nowacki and Abrams 2008).

Ecosystem resilience is described as the ability of an ecosystem to adapt to perturbations and to change 
or recover in such a way that maintains function, structure, identity, and feedbacks (Holling 1973, Walker et al. 2004). In the context of disturbancedependent forest types, such as those described above, managing for ecosystem resilience requires appropriate management prescriptions that create conditions mimicking the outcomes of historic disturbance regimes (Franklin et al. 2002, Palik et al. 2002, Drever et al. 2006). However, changes in ecosystem composition and structure since EuroAmerican settlement, in combination with widespread landscape fragmentation and increasing complexity of land ownership patterns, have created ecological and social conditions that make the reestablishment of historic disturbance regimes unlikely without purposeful and informed intervention (Cissel et al. 1999, Suding et al. 2004, Abrams 2005), i.e., enhancing the capacity of system actors to maintain resilience. For example, clear-cutting, that is, the removal of most overstory trees during a single regeneration harvest, can be useful for regenerating early- to mid-successional forest types, such as the oak-hickory forests of the eastern and midwestern U.S. (Johnson et al. 2002), but is often viewed by society as having objectionable outcomes. The social acceptability of such practices is crucial to the success of forest management (Bliss 2000), given that the majority of forestland in the U.S. is in private ownership (Butler and Leatherberry 2004). For this reason, policy makers and managers seeking to increase the resilience of disturbance-dependent forest types must thoroughly understand both ecological and social features of the system, and work to develop policies and management practices that are ecologically effective, socially acceptable, and enhance ecosystem resilience.

Traditional approaches to understanding and managing natural resources within coupled human and natural systems (hereafter termed socialecological systems; Gunderson and Holling 2002) have been sometimes ineffective or detrimental to ecosystem sustainability and resilience (Holling and Meffe 1996). In particular, research and management frameworks seeking optimal solutions have typically relied on linear predictive models and command-and-control methodologies. These approaches often fail to appreciate several important features of social-ecological systems, including the influence of cross-scale interactions, multiple stakeholder interests and perspectives, and the unpredictability of human behavior and decision making (Holling and Meffe 1996, Walker et al. 2002, Cumming et al. 2006). In response to some of the failings of traditional approaches to natural resource management, innovative research and management frameworks have been developed to understand and manage the resilience of social-ecological systems. Such resilience-based approaches include systems modeling and analysis (Allison and Hobbs 2006), alternative scenario development (Chapin et al. 2003, Peterson et al. 2003b), and stakeholder participation (Walker et al. 2002). In particular, Walker et al. (2002) propose a working hypothesis of a novel and integrative research approach, described as resilience analysis and management, which utilizes all three methods, with the goal of developing creative pathways to the future. In the process, they illuminate the biophysical and social aspects of the system, cross-scale interactions, and possible management actions and policy mechanisms that can contribute to building system resilience.

We adapted the initial steps in the resilience analysis and management framework to explore the state of oak-dominated ecosystems in the midwestern U.S., setting the stage for future scenario-development and quantitative assessments of resilience. Forest ecologists from the eastern and midwestern U.S. suggest that oaks have been an important component of the landscape for at least the last 10,000 years and thus provide vital habitat for numerous wildlife and plant species that have adapted to the unique ecological conditions they afford (Fralish et al. 1991, Abrams 1992, McShea and Healy 2002, Rodewald and Abrams 2002). However, forest surveys indicate an overall lack of oak regeneration with a high potential for future replacement by later successional forest types. Termed the "mesophication" of the forests (Nowacki and Abrams 2008), this successional process is largely occurring at sites where oak less successfully competes with more shade-tolerant, mesic broad-leaved deciduous species, particularly in nutrient rich and moist sites and where disturbance, such as fire, is largely now absent (Crow 1988). In fact, in the Central Hardwood Forest Region of the U.S., the historical prevalence of oak is attributed to centuries of American Indian burning practices, and current oak dominance has been linked to the intensive logging, fire, and grazing activities of Euro-American settlers (Abrams 1992, Johnson et al. 2002). In both cases, anthropogenic disturbance has promoted the regional dominance of oak; oaks typically are more 
fire adapted than later-successional tree species and readily stump sprout under the appropriate conditions (Burns and Honkala 1990).

Over the last century, fire suppression is largely viewed as accelerating the successional process in oak-dominated forests (Nowacki and Abrams 2008). However, other complex, and often interrelated, ecological and social factors, such as increased herbivory by white-tailed deer, the spread of invasive plant species, and ill-planned harvests have also been linked to limiting the competitive advantage of oak (Abrams and Nowacki 1992, Meekins and McCarthy 1999, Kittredge et al. 2003, Rooney and Waller 2003). In particular, highgrading, i.e., a selective harvesting method where only high quality, economically valuable, mature trees are harvested, decreases the overall genetic quality of a forest stand over time and also does not provide openings in the canopy that are large enough to allow adequate light for oak recruitment, thereby, favoring more shade-tolerant species (Johnson et al. 2002, Kittredge et al. 2003). Clear-cutting has been used to create suitable light conditions for oak, but this harvesting method can instead encourage succession to more shade-tolerant species if there is inadequate natural oak regeneration at the time of harvest (Abrams and Nowacki 1992). The layers of complex forces inhibiting successful oak regeneration suggest that the future of regional oak dominance and associated biodiversity are uncertain, if not imperiled (Fralish 2004). In response, natural resource agencies from various midwestern states have listed oak management as a priority (Iowa Department of Natural Resources 2005, Wisconsin Department of Natural Resources 2005). The steps required to achieve this priority, however, are poorly defined.

We sought to develop an integrative conceptual model and systems understanding of forest change and oak regeneration in the Driftless Area of the Midwest, illuminate potential leverage points from which to improve oak forest resilience, and provide a foundation for future scenario development and stakeholder participation. In addition to resilience, the concepts of adaptability and transformability form the basis for understanding social-ecological system dynamics (Walker et al. 2004) and are used to help interpret our study findings. Adaptability refers to the capacity of system actors to maintain system resilience, and transformability is the ability of actors to reshape the system when current ecological, economic, and social conditions appear unworkable (Walker et al. 2004). Our research approach included: (1) describing the state of the oak system; (2) identifying key biophysical, ecological, and social components and processes that influence oak ecosystem dynamics; (3) revealing within- and cross-scale interactions, dependencies, feedbacks, thresholds, and critical system uncertainties; and (4) developing an understanding of natural resource professionals' preferred attributes of future forest conditions in the region. These goals form the foundation of our systems analysis and are adapted from Walker et al. 's (2002) resilience analysis and management approach. As Walker et al. (2002) emphasize, this approach is designed to go beyond characterizing the system, and can identify points in the system where resilience to uncertain future changes may be increased.

\section{RESEARCH APPROACH}

\section{Study area: the Driftless Area of the Midwest}

The Driftless Area is roughly 5 million hectares in size, encompassing a part of the upper Mississippi River and portions of four states: southeastern Minnesota, southwestern Wisconsin, northeastern Iowa, and northwestern Illinois (Fig. 1). This region historically was a mosaic of tallgrass prairie, bur oak savanna, and deciduous forest (Albert 1995). Similar to other areas in the eastern and midwestern U.S., the Driftless Area landscape has been substantially altered since Euro-American settlement, with the majority of native cover types converted to agricultural lands, especially on the floodplains and level uplands (Prior 1991, Albert 1995). Currently, forests make up nearly one-third of the landcover (US Forest Service 2010), over half of which is described as oak-hickory forest type, while $25 \%$ are considered sugar maple (Acer saccharum) basswood (Tilia americana) forests (US Forest Service 2010). The proportion of forestland in the Driftless Area has increased over the last 20-30 years; however, oak-dominated forests have generally declined throughout the region (Knoot 2008). Nearly all, approximately $90 \%$, forestland is in private ownership (US Forest Service 2010) and most private land holdings are relatively small $(<20$ ha; Rickenbach et al. 2005).

Forestlands in the Driftless Area are of ecological as well as social importance, because they are part of the working rural landscape of the region and 
Fig. 1. Driftless Area of the midwestern U.S., encompassing portions of four states.

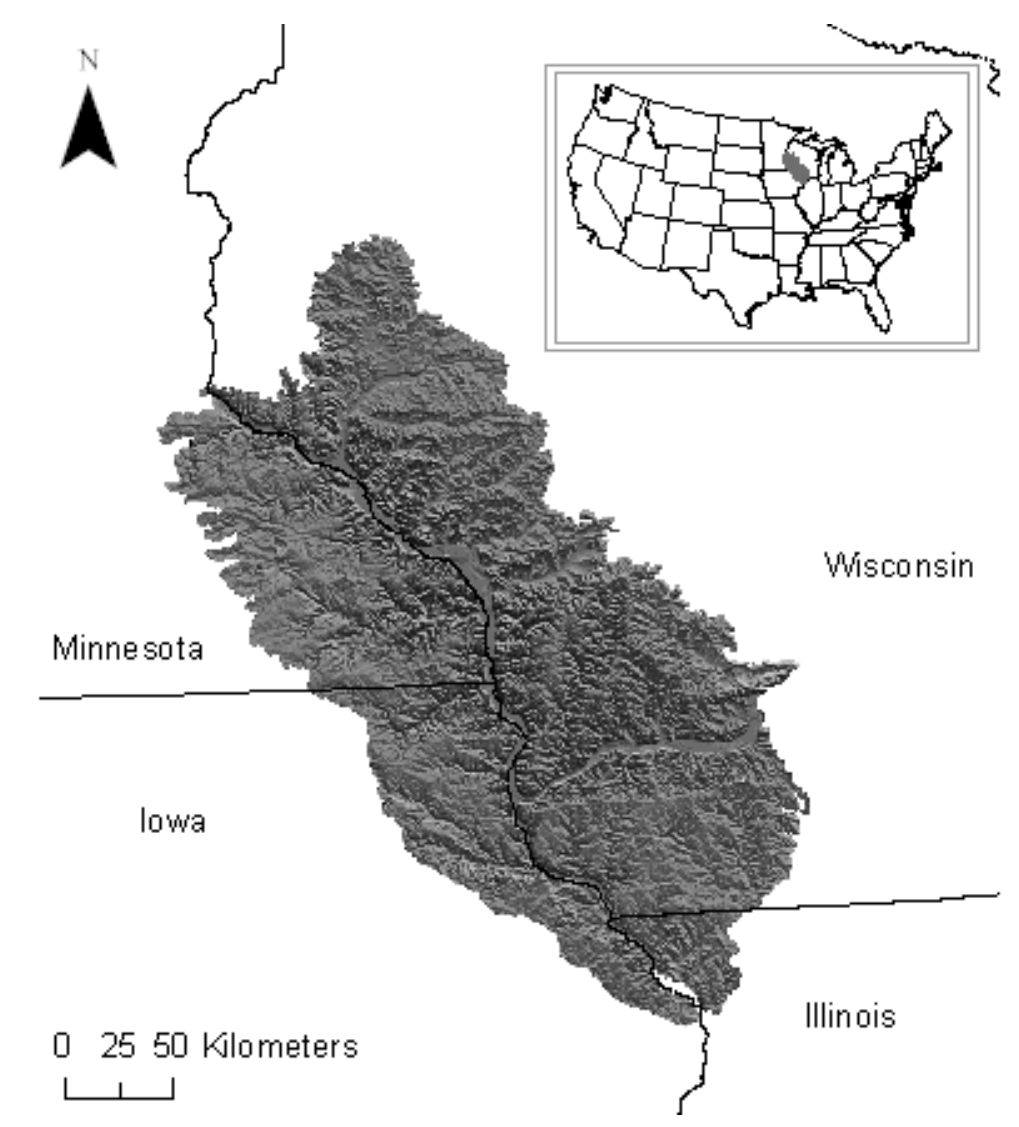

provide valuable ecosystem goods and services (Jacobs and Wray 1992). The forest cover in this region provides habitat for a variety of wildlife and plant species (Pusateri et al. 1993, Wisconsin Department of Natural Resources 2005). In addition, the forested slopes are essential to soil conservation efforts, because the potential for soil erosion and agricultural runoff is high in this steeply dissected landscape (Trimble and Crosson 2000). As a social and economic asset, the steep forested slopes and trout streams pose an attractive vacation destination for people from three proximal major metropolitan areas: Minneapolis, Minnesota; Madison and Milwaukee, Wisconsin; and Chicago, Illinois. Although the amenity value of the Driftless Area contributes to the local economy, it is also a potential threat to forestland. Between 1940 and 2000, the Driftless Area experienced considerable housing growth (50-200\% across the region; Radeloff et al. 2005) following the trend in other areas in the Midwest that are rich in amenity resources and within close proximity to urban areas (Gustafson et al. 2005). Moreover, oak forests are more frequently converted to residential development in comparison to other cover types, such as residential housing, especially near lakes and rivers (Kromroy et al. 2007).

\section{Qualitative Interviews}

We used a qualitative research framework to provide insight into the key features of the oak forest system, recognized as a subsystem of the broader social-ecological landscape. Although quantitative methods are useful for answering many important ecological and social questions, such methods require substantial prior knowledge of system components and dynamics. Qualitative social science research methods can offer further insight 
into complex issues, about which little is already known and for which innovative and flexible strategies are needed because of large uncertainties in the system (Strauss and Corbin 1990). Given the paucity of information on the economic and social factors influencing oak regeneration, qualitative methods were appropriate for addressing our objectives.

In landscapes composed of primarily privatelyowned forestland, natural resource professionals can serve as key agents in the communication of regional forest conservation goals (West et al. 1988). Drawing upon adoption-diffusion terminology, natural resource professionals can be termed "change agents," or individuals who are directly involved in promoting or disseminating new knowledge or ideas (Rogers 2003). These professionals have a unique and multifaceted perspective, often having to negotiate the complex ecological and social context related to forest management on private lands. Therefore, natural resource professionals served as the main stakeholder group to provide insight into our research objectives.

Between October 2005 and May 2006, the lead author conducted semistructured, in-depth, interviews with 32 natural resource professionals who worked in the Wisconsin $(n=8)$, Iowa $(n=9)$, and Minnesota $(n=15)$ portions of the Driftless Area; these three states include a substantial portion of the study region (Fig. 1). Participants were identified through a nonrandom selection process, described as snowball sampling, in which interviewees recommend other participants (Esterberg 2002), with the goals of interviewing individuals that had regular contact with private landowners and had a substantial amount of experience. Initial interviewees were located using phone directories and web searches, and were contacted because of their natural resource position. We sought to obtain diverse viewpoints; thus, the participant pool consisted of state agency foresters $(n=13)$, other publicly employed natural resource specialists, e.g., forestry extension specialists $(n=5)$, privately employed forestry professionals, e.g., consulting foresters $(n=8)$, and those employed by the timber industry, e.g., sawmill owners and loggers $(n=6)$. We asked research participants for recommendations of other professionals who may have in-depth and/ or a unique understanding of the system. Consequently, interviewees tended to recommend professionals who had worked in the region for a relatively long period of time; the majority of interviewees had at least 20 years of experience in the region. Five interviewees had less than 10 years of experience; however, because of their position and/or level of engagement with private landowners, they were identified by other interviewees as having a unique understanding of the system. We stopped recruiting new research participants after later interviews did not raise substantively new insights (Patton 2002).

Each interview followed a similar overall format (Appendix 1); however, characteristic of semistructured interviews, the follow-up questions, or probes, were chosen according to individual participant's responses (Esterberg 2002). To broadly explore oak management as related to ecological and social contextual factors, we asked questions concerning forest resources and private lands management in general, and also inquired directly about the oak forest type (Appendix 1). The length of the interviews varied, ranging between 23 and 107 minutes, and averaged 49 minutes. Roughly half of the interviews $(n=17)$ were conducted in person and the other interviews by telephone; interviews were digitally recorded and transcribed.

To analyze the interviews, sections of the transcribed text were coded and themes were developed using an "open coding" process (Esterberg 2002). The codes, themes, and thematic categories represent frequently encountered perspectives by the interviewees. However, ideas and perspectives that were mentioned rarely or sentiments that were contrary to the majority of opinions were also important to interpreting the findings (Strauss and Corbin 1990). The lead author used NVivo 7 qualitative analysis software (QSR International 2006) to assist with data management and analysis. We provide quotations from interviews to illustrate key findings (Appendix 2).

\section{Systems Analysis}

Systems thinking offers a basis for understanding and designing mechanisms for building resilience in complex systems (Walker et al. 2002, Allison and Hobbs 2006). In particular, systems theory provides the foundation for the holistic approach to understanding resilience, with attention to not only scale and system components, but relationships as well (Checkland 1981, Allison and Hobbs 2006). For example, systems theory suggests that complex 
systems exhibit emergent properties that cannot be understood from examining individual components, but instead result from critical relationships, i.e., feedbacks and dependencies, among components (Checkland 1981). Thus, systems thinking embraces a holistic rather than reductionist perspective and has contributed to the development of numerous approaches to problem solving, including systems agriculture, management cybernetics, and management science, i.e., operations research (Ison et al. 1997).

We adopted a soft systems approach, drawing from the interview data and our theme development associated with the open coding process, to create causal loop diagrams that highlight key system variables and processes, relationships, and positive and negative feedbacks from the perspectives of natural resource professionals. Our open-ended interviews yielded varied perspectives from which to build the conceptual model. We included system features that received considerable attention by interviewees and/or offered a unique understanding and description of system dynamics; thus, topics that were not fully developed or discussed in the interviews are not included as key features in the conceptual model but may be discussed in the results. Indicative of causal loop diagrams that represent positive and negative feedback loops, a positive sign in our model linking two variables, such as between variable $A$ and $B$, indicates that $A$ adds to $\mathrm{B}$, or a change in $\mathrm{A}$ produces a change in $\mathrm{B}$ in the same direction. A negative sign linking two variables indicates an inverse relationship. To determine whether a negative or positive feedback occurs, we counted the number of negative causal links within the loop; an even number of negative links indicates a positive feedback and an odd number of negative links indicates a negative feedback.

\section{RESULTS}

Our findings are arranged in three main sections: (1) natural resource professionals' perspectives on the state and resilience of the system, including a conceptual model of key system components, relationships, and feedbacks; (2) critical system thresholds, interactions, and uncertainties; and (3) interviewees' preferred attributes of future forestland.

\section{The state and resilience of the oak-dominated social-ecological system}

We found that most professionals perceived the overall forest as degraded, with widespread decline in oak regeneration. Interviewees pointed to the effects of ecological, economic, and social factors on the forest resources and oak in particular; these factors influenced the system at different spatial and institutional scales (Appendix 2). In particular, landowners' decision to adopt oak management practices figured prominently in the state of the system (for further description, see Knoot et al. $2009,2010)$ and was central to our integrative conceptual model (Fig. 2), as created from the collective perspectives of natural resource professionals. The whole system model (Fig. 2) is composed of subsystem components that reflect the three main thematic categories, i.e., the main features of the system, which we found to be directly and indirectly associated with landowner decision making. These categories include: (1) the direct and indirect influence of ecological factors; (2) the inhibiting effect of macrolevel socioeconomic processes; and (3) personal relationships promote oak-appropriate decision making. In combination, these system components and processes comprise the conceptual model of the Driftless Area oak forest social-ecological system. For ease of describing and discussing feedback loops in the system, we designated loops as ecological (E), socioeconomic $(\mathrm{S})$, and social-ecological (SE) in nature. Furthermore, we present a depiction of the main features of the system (Fig. 3), in which we identify the relative spatial scale, i.e., local to landscape, at which the features and processes occur, and the direction, i.e., negative to positive, of influence on oak regeneration. The arrows in Figure 3 indicate a simplified view of the overall direct and indirect effect of the various features on site-level factors, specifically landowner behavior, as emphasized by the interviewees; whereas system complexity, including multiple feedbacks within the system, is thoroughly represented in Figure 2.

\section{Category 1: The direct and indirect influence of ecological factors}

Interviewees identified several ecological factors that influenced landowners' decision to adopt oak management practices, most often indirectly through their influence on the economic cost of oak regeneration occurring at the site-level (Fig. 2). Following the central positive social-ecological 
Fig. 2. Integrative conceptual model identifying ecological, social, and economic system components that influence the oak forest social-ecological system, as identified through in-depth interviews with 32 regional natural resource professionals in the Driftless Area of the Midwest. We identify feedback loops as primarily ecological (E), socioeconomic (S), or social-ecological (SE) in nature, with -/+ indicating the direction of the relationship for each component connection and feedback loop.

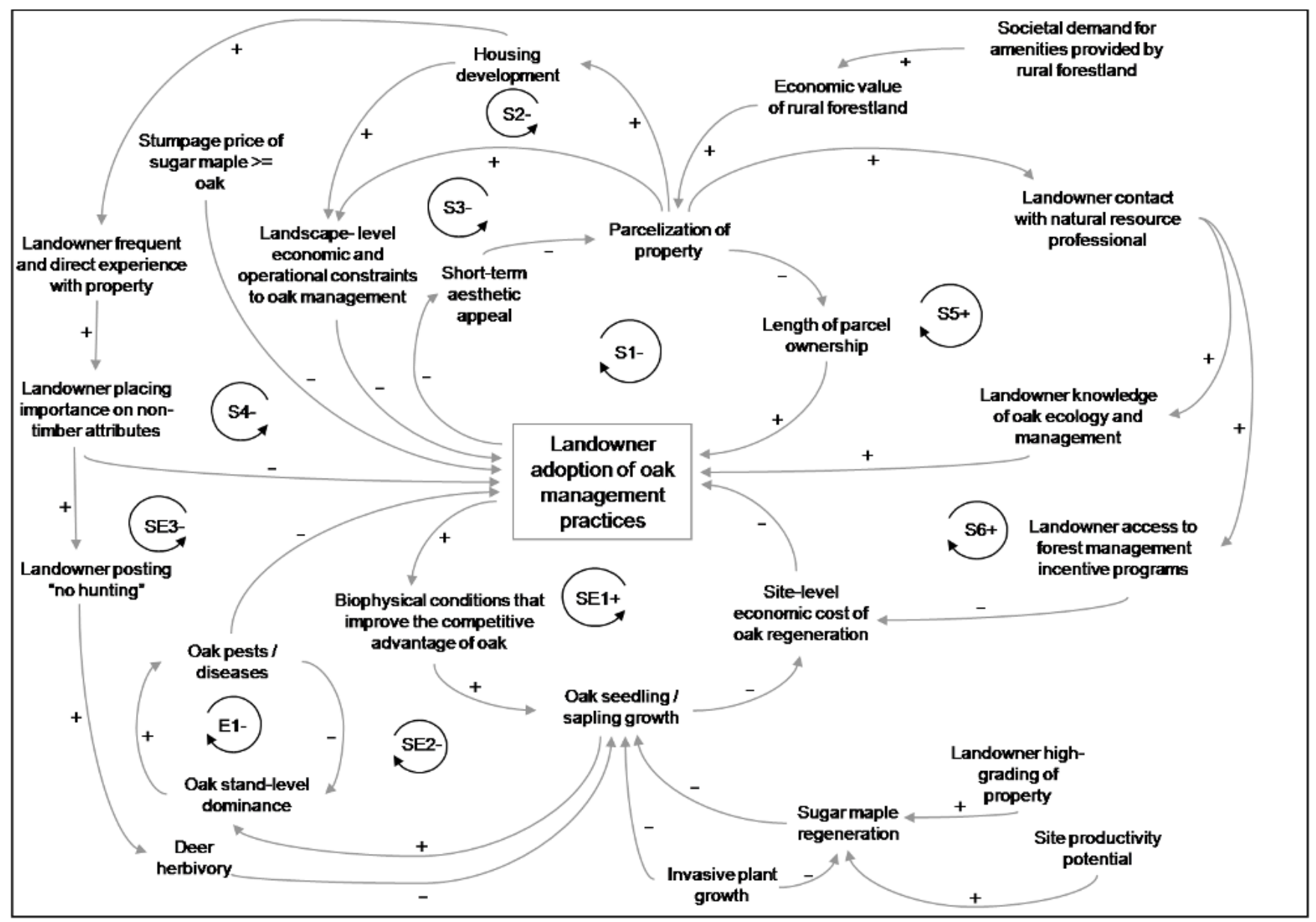

feedback loop (SE1+, Fig. 2), landowner adoption of oak management practices, e.g., prescribed fire, extensive overstory tree removal, and manual removal of understory vegetation, improves the biophysical conditions for oak regeneration, thereby increasing oak sapling and seedling growth, and decreasing the economic cost of regenerating oak. Interviewees noted, for example, that when a stand contains adequate advanced regeneration of oak, fewer practices, e.g., direct seeding and planting of oak, are needed for re-establishing oak at a site. A lower economic cost for oak regeneration increases the likelihood that landowners will choose to adopt oak regeneration practices in the future.
The two negative feedback loops link the spread of invasive oak pests and diseases to landowner oak management decisions (SE2- and E1-, Fig. 2), and serve to dissuade landowners from adopting oak management practices. The majority of interviewees remarked on an increase in the impact of oak pests and diseases on mature oak stands throughout their region. They most often cited gypsy moth (Lymantria dispar), two-lined chestnut borer (Agrilus bilineatus), and oak wilt, caused by a fungal pathogen (Ceratocystis fagacearum), as main threats to the oak resource. Such pests and diseases negatively impact mature oak trees and, thus, standlevel dominance. In turn, they can limit the future 
Fig. 3. The relative spatial scale, direction of influence, and general relationships of key system features in the context of oak regeneration, as identified through an analysis of in-depth interviews with 32 regional natural resource professionals in the Driftless Area of the Midwest.

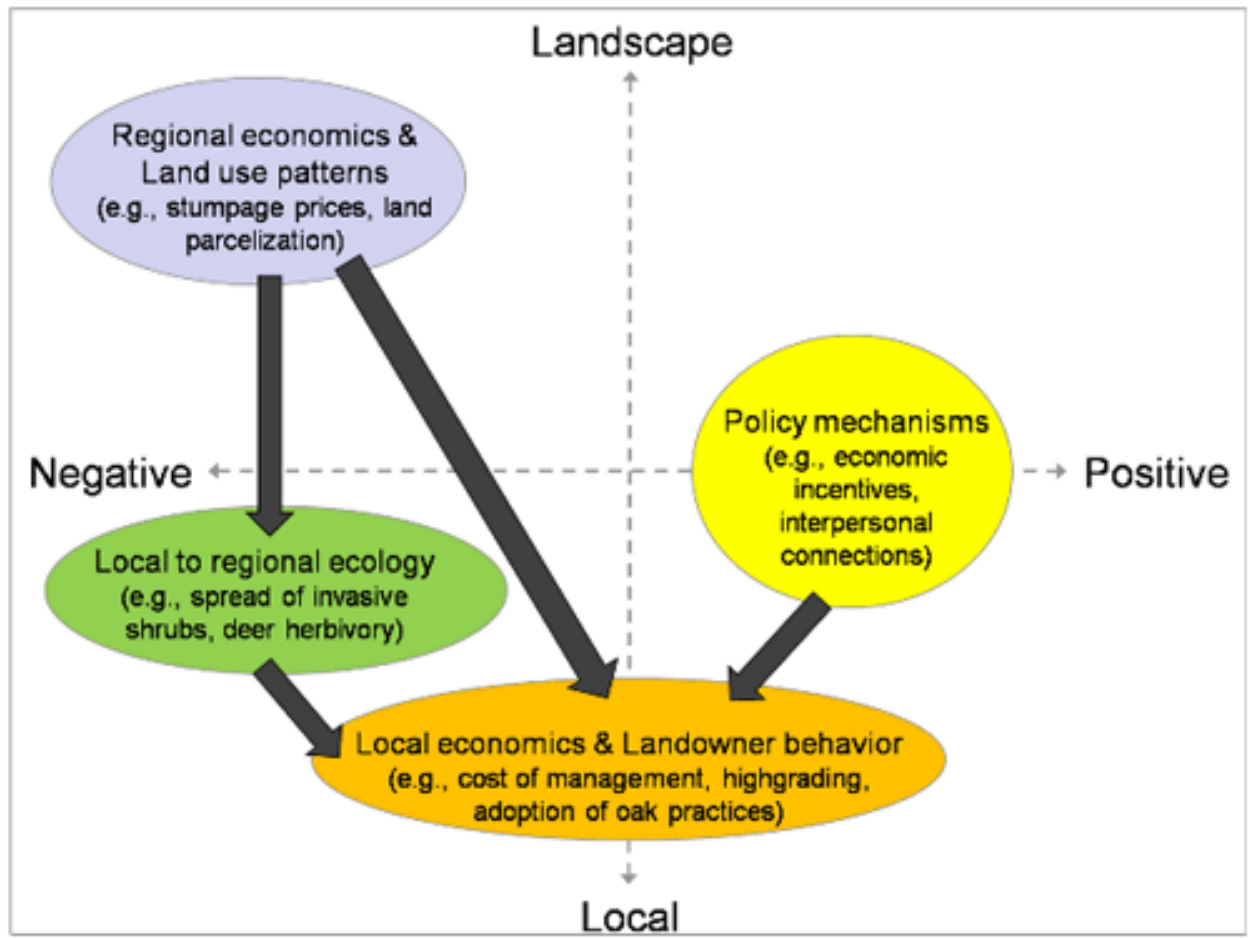

spread of pests and diseases of oak (E1-, Fig. 3). Several professionals noted that landowners are less likely to choose to adopt oak regeneration practices if future oak-dominated stands are perceived to be at risk of infestation (SE2-, Fig. 2).

The majority of natural resource professionals have found white-tailed deer (Odocoileus virginianus) herbivory, invasive plant growth, and the advanced regeneration of sugar maple in the understory as negatively impacting oak seedling and sapling growth, thereby increasing the economic cost of oak regeneration and decreasing the likelihood that landowners will adopt oak management practices (Fig. 2). For example, to prevent deer herbivory, the professionals recommended the use of tree shelters, an additional cost to landowners. Invasive plants were also commonly viewed by the interviewees as a top threat to oak in the region, directly inhibiting oak seedling and sapling growth, and requiring increased effort and expense to remove. However, the professionals noted that invasive plants also inhibit the regeneration of other tree species, including sugar maple. The professionals cited European buckthorn (Rhamnus cathartica) and garlic mustard (Alliaria petiolata) most often, among over a dozen other invasive plant species. Although not prominent in our discussions with professionals, one professional expressed caution with respect to oak regeneration practices, remarking that the extensive disturbance required to regenerate oak can also promote invasive species growth. This perspective is consistent with experimental evidence indicating a positive relationship between garlic mustard reproduction and light availability (Meekins and McCarthy 2001). Thus is the potential for a negative feedback in the system surrounding the disturbance of oakappropriate management, which could increase invasive plant growth, decrease oak seedling and sapling growth, and increase the economic cost of future oak management options. 
The increased advance regeneration of sugar maple in many forest stands was thought to be promoted by local site productivity and past and current land management decisions, specifically high-grading (Fig. 2). Many interviewees expressed their perception that high-grading was a product of short term economic decision making by private landowners, and carried out, and sometimes encouraged, by some individuals in the logging industry. The professionals remarked that highgrading often retained the overstory canopy and thus favored later-successional, more shade-tolerant species, such as sugar maple.

Notably and somewhat surprisingly, the natural resource professionals did not discuss climate change as an issue that they perceived as affecting oak regeneration and thus climate change was not included in the model, as reflecting the professionals' perspectives. However, there is the potential for climate change to cause significant changes in forest composition and specifically oak in the region. For example, some ecological models suggest that climate change will result in an increase in suitable conditions for oak, specifically white oak (Quercus alba; Prasad et al. 2007). Climate change is further discussed below and may be an important component to include in future alternative scenario development, stakeholder discussions, and quantitative systems modeling efforts.

\section{Category 2: The inhibiting effect of macrolevel socioeconomic processes}

The second main group of system components and processes includes predominately macrolevel economic and social variables that were noted by professionals to influence the oak system and, specifically, landowner adoption of oak management practices (Fig. 2). For example, several of the interviewees remarked on the strong market price for sugar maple, which in the recent past was equal to or exceeded the stumpage price for red oak (Quercus rubra). These market forces were thought to decrease the likelihood of landowners choosing to adopt oak regeneration practices, especially given that managing for oak was considered more expensive than managing for sugar maple.

We also found that the professionals were deeply concerned about the widespread trend in forestland parcelization; they connected parcelization to the fragmentation of once contiguous forests by residential housing development. The main negative socioeconomic feedback (S1-, Fig. 2) in this part of the system centers on forest parcelization. Many interviewees believed that societal demand for the amenities provided by rural forestland had contributed to its increasing economic value and, thus, increased the likelihood that a landowner would choose to sell a portion of their land, i.e., parcelization. The interviewees also remarked that oak management practices often result in a decrease in the short term aesthetic appeal of the property. Visual aesthetics were thought by interviewees to be a top priority of landowners (Knoot et al. 2010). Since oak management often causes a short term decline in property aesthetics, several professionals posited that once landowners view the outcomes of oak management prescriptions, i.e. extensive overstory removal, landowners may be more likely to sell and parcelize their property. Landowners that intend to own their property for only a short duration are also thought as less likely to adopt oak management, which is a long term endeavor. Together these factors form a negative socioeconomic feedback loop in the system and constrain landowner adoption of oak management practices.

We also found that interviewees saw parcelization as directly and indirectly increasing landscape-level economic and operational constraints to oak management, thus decreasing the likelihood that landowners adopt oak management practices (S2and S3-, Fig. 2). For example, the professionals noted the challenges associated with carrying out timber harvests, a tool for encouraging oak regeneration, on small parcels and near houses (Knoot et al. 2010). The professionals have also found that with an increase in exurban housing development, more landowners have direct and frequent contact with their forested property. They linked this phenomenon to an increase in the proportion of landowners placing importance on the nontimber attributes, e.g., aesthetics, recreation, privacy, of their lands; values that most interviewees have found to most often conflict with the perceived outcomes of oak management practices and, therefore, a deterrent to landowners' adoption of these practices (S4-, Fig. 2). Conversely, a few professionals noted that landowners interested in enhancing wildlife habitat of their land, often for hunting purposes, expressed interest in regenerating oak. However, visual aesthetics and the economic cost of oak regeneration methods were found to 
often outweigh landowner values placed on oakassociated wildlife habitat.

Several natural resource professionals also noted an increase in the number of landowners that post their property against public hunting, deemed a result of their own interest in hunting their property and also the importance they place on privacy. As an important relationship between social and ecological components of the system, several of the interviewees linked the decline in public hunting of privately owned lands to an increase in deer herbivory and connects human behavior to an ecological factor inhibiting oak regeneration and landowner adoption of oak management (SE4-, Fig. 2).

\section{Category 3: Personal relationships promote oak-} appropriate decision making

Interviewees placed high importance on their relationships with landowners (Fig. 2). The professionals described their interactions as increasing landowners' knowledge of oak ecology, the wildlife benefits of oak, and potential management prescriptions, as well as providing landowners access to forest management incentive programs (Knoot et al. 2010). These features directly and indirectly increase the likelihood that a landowner will adopt oak management practices, creating positive feedbacks in the system (S5+ and S6+, Fig. 2). Consistent with these findings, Huntsinger et al. (1997) found that landowners who were informed about the conservation value of oak were more likely to adopt oak-appropriate management practices. Thus, although parcelization can reduce the likelihood for oak management by landowners (Fig. 2), there are potential beneficial outcomes. For example, the professionals described parcelization as often resulting in a greater number of landowners seeking forestry assistance, which creates opportunities for building relationships and supports landowner decisions toward managing for oak.

\section{Critical system thresholds, interactions, and uncertainties}

\section{Perceived system thresholds}

We identified two main ecological thresholds that were discussed, although not quantified, by interviewees, namely the level of deer herbivory in the region and the amount of resource competition, i.e., population levels of woody and herbaceous understory plants, facing oak regeneration. The professionals suggested that, once above a certain level of herbivory or competition, the expense, i.e., economic and personal effort, to counteract these processes exceeded what most owners were able and/or willing to spend. Also, several professionals noted that at some threshold, the current techniques for removal of competing plants became ineffective.

Many interviewees also noted the threshold related to parcel size and the feasibility of management options. In their experience, once parcelization had progressed to the point where parcels fell below a certain size, the economies of scale became critical to determining whether a timber company would be able and/or willing to harvest on that parcel. Notably, the presence of policy mechanisms to help prevent reaching system thresholds were absent from our discussions with the professionals (Fig. 3).

\section{Cross-scale interactions}

Through our analysis of interviews and conceptual modeling approach, we identified several crossscale, i.e., temporal, spatial, and institutional interactions. First, we found that the length of parcel ownership, i.e., the typical time that landowners experience their properties, was perceived to influence their land management priorities, such that shorter land tenure resulted in landowners placing greater importance on the immediate outcomes of forest management practices. As noted by the interviewees, this phenomenon, often augmented by forest parcelization, is in direct conflict with the time frame required to regenerate an oak forest following harvesting; it takes at least 10 years for the overstory canopy to close and several decades to grow a mature oak forest. Thus, regenerating an oak forest requires a time period that usually exceeds the typical land tenure, suggested to be less than 15 years.

In addition, we found that parcel-level land management decisions can have a regional influence on oak regeneration. For example, interviewees expressed the notion that a landowner posting "no hunting" on their property increased deer fitness at their site, potentially contributing to regionally high population levels and seedling herbivory. Thus, site-level expenses for oak management are influenced by regional level ecological (deer population growth) and social 
processes (human behavior). Invasive plant growth was also thought to influence site-level expenses; however, multiparcel, regional, national, and global issues all contribute to the spread of invasive species. Finally, the natural resource professionals identified both macrolevel factors that influenced forestland parcelization, e.g., regional property values, and site-level factors, e.g., property visual aesthetics, that together served to demote individual landowner decision making to perpetuate oak (Fig. 3 ). Of note is the absence of policy mechanisms to address the macrolevel factors that directly and indirectly were thought to affect landowner decision making.

\section{System uncertainties}

The majority of natural resource professionals believed that they were well equipped with a variety of silvicultural tools for encouraging oak regeneration, but many interviewees felt uncertain about how to manage and prepare for the influence of future invasive pests, disease, and plants on forest resources. In addition, most of the interviewees perceived the continued parcelization of forestland and exurban sprawl as looming threats to the forest resources in general, and oak in particular, and were unsure of how they could personally counter these trends.

\section{Preferred attributes of future forestland}

We asked the professionals about their preferred attributes of the future forest resources and of oakdominated forests in particular. The main responses we encountered were tied directly to some of the main uncertainties that they identified in the system. We identified three main attributes: (1) diverse and resilient forest stands, (2) secure forest extent, and (3) maintenance of an oak component at stand and/ or landscape scales. Because invasive pests, diseases, and plants were of great concern to the professionals, most interviewees told us that they would like to see forests, at the stand level, that contain a diversity of species and age classes. They linked this diversity to the ability of the forest to withstand future pests and disease outbreaks, i.e., enhancing system resilience to these potential disturbances and ensuring future access to valued tree species. Interviewees also preferred diverse age-classes, also in an effort to provide stable resources for future generations.
The security of the resource was also sought by many interviewees, as reflected in their preference for maintaining or expanding the amount of forest cover on the landscape. This preference was linked to their concern over further exurban housing development and forest parcelization. Both factors were thought to reduce future access to the timber resource by either eliminating the resource through clearing of the land for housing, or increasing the constraints to timber harvesting by reducing parcel size. Thus, we regularly heard their preference to "keep forest as forest."

Finally, given the important benefits that oakdominated forests provide to society, we were surprised to encounter the frequent preference for maintaining an "oak component," at stand and/or landscape scales, as opposed to maintaining oakdominated forests. Many interviewees suggested that a reduction in the dominance of oak in the future was acceptable, as long as "some" oak was perpetuated; interviewees' definitions for what proportion of oak was considered acceptable varied considerably and were qualitative as opposed to quantitative descriptions. We found this preference to be tightly linked to the overall system components and feedbacks (Fig. 2). The majority of ecological, economic, and social factors constrain landowner adoption of oak management practices, either directly or indirectly (Fig. 2); 7 of the 10 feedback loops are negative with respect to landowner adoption of oak management practices (Fig. 2). Thus, the professionals appeared to perceive oak management as a costly and frustrating endeavor, both personally and from the standpoint of private landowners. Many viewed an oak component, as opposed to oak dominance, as more realistic and even preferable given current pressures, especially those associated with oak pests and diseases. Thus, to safeguard the future resources, more diverse stands appeared to be preferable to the professionals. However, there remains the question concerning the intensity and thus cost of management needed to maintain a smaller "oak component" (Povak et al. 2008).

In addition, many professionals believed that the trajectory of forest change, i.e., successional shift to later-successional species, was well established. In other words, current thresholds have already been crossed, making management for oak dominance too costly to be attempted. We also heard from a professional about his/her concern that promoting oak could also lead to the loss of future resources. 
If landowners are dissatisfied with oak management outcomes, they may sell and parcelize their property, potentially contributing to further exurban housing development.

\section{DISCUSSION}

Through our analysis of the interviews, we found that the collective perspectives of the natural resource professionals highlighted important aspects of oak system resilience, offered points for enhancing system adaptability, and suggested key system uncertainties that can be used to develop future scenarios for preferred outcomes that safeguard valued ecosystem goods and services provided by privately-owned forestland in the Midwest.

\section{Resilience of oak social-ecological systems}

The landscape in the Driftless Area prior to and just following Euro-American settlement provided a set of conditions that favored disturbance-dependent oak forests, with later-successional forest types composing a smaller proportion of the landscape than today. This landscape can be thought of as a "stability landscape," with various forest types represented as stability domains (Gunderson 2000). Resilience refers to the attributes that allow the system to remain in that particular domain, retaining key system components, processes, and functions despite disturbance. There are four main attributes that describe system resilience: (1) latitude, or the maximum amount a system can change before reaching a threshold; (2) resistance of a system to change; (3) precariousness, or how close the system is to a threshold; and (4) panarchy, which refers to the cross-scale system processes; the system at one focal scale is influenced by systems components and processes at broader and finer scales (Walker et al. 2004). The ball and cup heuristic (Gunderson 2000) provides a visual of the four features of resilience; the ball represents the state of the system and the cup is the stability domain, with one or more cups forming the stability landscape.

The natural resource professionals clearly articulated a change in the shape of the stability domain and stability landscape over time (Fig. 4, adapted from Nowacki and Abrams 2008). Wider domains, i.e., greater latitude, with steeper sides, i.e., greater resistance to change, indicate increased system resilience. The stability domain for oak appears to have decreased in latitude and resistance, with increasing precariousness, because of both ecological and social system features (Fig. 4). For example, an important threshold in the system was identified as the proliferation of understory plant competition. With a change in the disturbance regime in the region, namely fire suppression and high-grading, more shade-tolerant species have thrived in the understory, decreasing system resistance to change. The invasion of non-native plants in the understory has also contributed to reducing resistance, as well as moving the system closer toward the threshold, i.e., increasing precariousness. Further decreasing system resilience, deer herbivory appears to have reduced the latitude, or width, of the domain, inhibiting oak regeneration and moving the threshold closer to the current state of the system, i.e., with less oak regeneration due to herbivory, there is a lower threshold for understory plant competition before the system shifts into an alternate state (Fig. 4).

Adoption of oak management practices, such as prescribed fire, could help to retain the shape of the oak stability domain and enhance system resilience. However, forest parcelization and exurban development, in addition to the ecological factors described above, have contributed to reducing the likelihood that landowners adopt oak management practices, including prescribed fire. The main alternatives to oak management were typically noted to be high-grading and no management, which alter the shape of the stability domain for oak and potentially the overall stability landscape. For example, widespread high-grading and lack of management by landowners appears to shrink the stability domain for oak while increasing the latitude and resistance of the domains of other forest types, e.g., sugar maple-basswood. However, the social relationships between resource professionals and landowners may serve to support oakappropriate landowner management decisions (positive driving force, Fig. 3) and increase the stability domain for oak. Furthermore, if the barriers to oak management are minimized, we would expect that the landowners, who hold preference for oak because of their interest in providing high quality wildlife habitat, as noted by the interviewees, would be more likely to adopt oak management techniques. Given that our findings are based on the perspectives of natural resource professionals, future research that assesses landowner perspectives of oak management would offer further clarification of the 
Fig. 4. The stability domains and landscape of the historic and current forest landscape in the Driftless Area of the Midwest, as portrayed through a ball and cup heuristic (adapted from Nowacki and Abrams 2008). The state of the system is the ball and the stability domains are represented as the cups (i.e., oak and maple). The stability landscape is composed of one or more domains. The transition between domains occurs where the conditions in the system reach a critical level or the system threshold (T). Overall system resilience, or ability of the system to retain the same structure and function, is influenced by: system resistance $(\mathrm{R})$ to change; system latitude $(\mathrm{L})$, or the maximum amount that the system can change before reaching a threshold, or system latitude; and the precariousness $(\mathrm{P})$, or nearness to a threshold. The current oak system has decreased overall resilience to change because of a combination of ecological, economic, and social drivers, with a potential shift to a stability landscape dominated by maple or uncertain and novel stability domains.
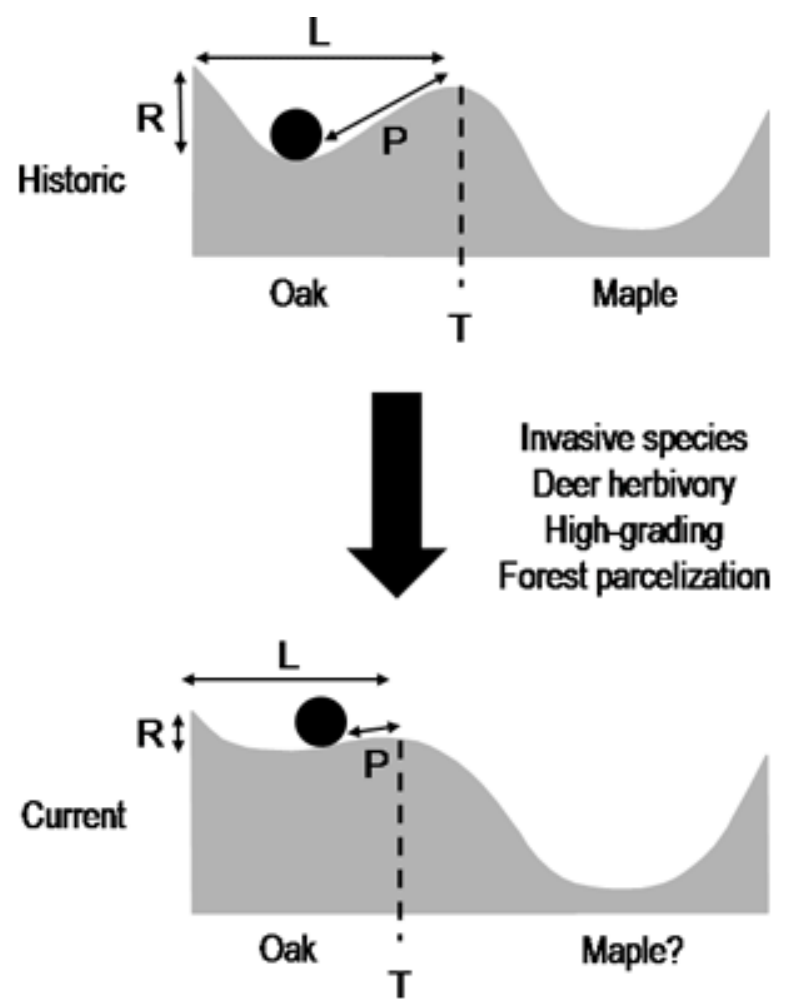

proportion of landowners who hold values and beliefs consistent with oak management techniques and the relative importance of landowner connections to natural resource professionals with respect to their oak management activities.

In the northeastern U.S., where ownership patterns closely parallel those in our study region, Kittredge et al. (2003) documented the pervasive and nonrandom pattern of high-grading across the landscape, which they expect to result in forest and landscape homogeneity. The results from our interviews suggest that with the decline in oakdominated forests, homogenization of the forest landscape is also possible in our region, with reduced oak-associated biodiversity. The potential for creating new stability domains with novel species compositions (Seastedt et al. 2008) also exists within this landscape, such as forests with a larger component of invasive shrub species. This type of shift in the stability landscape was deemed highly undesirable by the natural resource professionals, but they felt they did not have the capacity to cope with it. These natural resource 
professionals typically apply their expertise to forest stand and properties, whereas management of invasive plants requires a broader-scale approach, i.e., attention to system panarchy.

Panarchy is the fourth attribute that helps to describe system resilience and relates to the importance of scale; the state of the system at a particular focal scale, i.e., oak-dominated forests, is influenced by broader, i.e., forest landscape, and finer, i.e., oak tree, scales (Gunderson and Holling 2002, Walker et al. 2004). We identified critical cross-scale interactions that offer the potential to influence oak system resilience. For example, climate change, although not included in the model, market forces, i.e., stumpage prices for oak and maple, invasive species spread, societal demand for rural forestland, and forestland parcelization and exurban sprawl, operate at broader scales, from regional and global, but have cascading effects on landowner decision making and oak regeneration at the forest stand level (Fig. 3). Thus, policy mechanisms and management approaches must address these multiscale system drivers. One such approach is cross-boundary cooperation, where neighboring landowners coordinate their management to achieve landscapelevel outcomes, such as timber supply or invasive species removal (Kittredge 2005). Where forest parcelization and exurban sprawl contribute to less marketable timber volumes, cross-boundary cooperation offers the potential to broaden the scale of management, with potentially beneficial ecological, economic, and social outcomes (Kittredge 2005). For example, because invasive plants and deer are not attentive to political borders, cross-boundary cooperation is essential to tackling these critical constraints on oak regeneration.

\section{Social capacity for adaptation and transformation}

In the context of managing for oak in the region of our study, removing the constraints on this disturbance-dependent system requires the collective effort of actors operating at multiple institutional scales, e.g., individual landowners, natural resource professionals, conservation organizations, and regional and national-level policy makers. As mentioned previously, various natural resource organizations have listed oak management as a priority. However, our findings suggest that, in the face of continued parcelization, the natural resource professionals were most interested in bolstering system resilience at the scale above oak-dominated forests, i.e., forest landscape, seeking to ensure future access to forest-related ecosystem goods and services that would diminish with a shift from forest to nonforest cover, e.g., agricultural land and residential housing. To achieve this goal, many professionals accepted a loss of resilience in oak forests, i.e., the shrinking of the oak system domain, especially if the system shifts to sugar maplebasswood, a system deemed economically beneficial and more palatable to landowners. However, a consistent and widespread loss of oakdominance could have cascading ecological effects on the numerous species that depend on the conditions afforded by oak forests (Fralish 2004). Although humans and markets may adapt to the shift in availability of the timber resource, the future of oak-associated flora and fauna is questionable. In addition, the interviewees stated that less intensive forest practices were acceptable and often preferred by landowners. However, taken in the aggregate, the decisions of the numerous landowners in the region to selectively harvest their forests may result in overall landscape homogeneity (Kittredge et al. 2003), with a loss of resilience at this broader scale.

Although not directly discussed by interviewees, climate change may be a critical system uncertainty. Although the interviewees regarded the shift in the stability landscape toward sugar maple-basswood forests potentially economically advantageous, this shift may be unstable in the long term. For example, climate change models point to a decline in suitable conditions for sugar maple, with an expansion in the habitat appropriate for white oak (Prasad et al. 2007). A decline in oak-dominated forests in the short term, however, would decrease the potential for natural regeneration of future oak forests, and the expense of restoring oak may then be cost prohibitive despite suitable ecological conditions (Nowacki and Abrams 2008). Therefore, if the domain for sugar maple shrinks because of climate change, there is potential for an increase in a domain that includes novel species compositions, including undesirable species such as European buckthorn.

\section{CONCLUSIONS}

If the resilience of oak forests is deemed socially desirable, there must be dialogue among key regional stakeholders to design proactive approaches that address the multilevel constraints to oak management and capitalize on the 
opportunities for influencing landowner behavior and system resilience, i.e., encourage relationships between the professionals and private landowners, develop oak-specific economic incentives. However, there are possible costs to managing for oak, such as the potential spread of invasive plants, as noted in the literature, and further parcelization, as found in our study. Given system uncertainties and the current trajectory of change, there is a need to envision alternative preferred system states and create practical solutions that can prevent the loss of valued ecosystem goods and services due to shifts toward undesirable systems, such as nonforest cover. Such envisioning of alternative futures is crucial to system transformability (Peterson et al. $2003 a$ ), which is the capacity of system actors to reshape the stability domain while maintaining valued ecosystem goods and services (Walker et al. 2004). The natural resource professionals provided us with preferred attributes of future forestland conditions, including ready access to valued timber species, a halt to further forest parcelization and exurban housing development, and the maintenance of the forest extent. However, steps toward achieving these goals appeared to be ill defined. As the future of non-native species invasions, forest parcelization, and ecological conditions associated with climate change remain uncertain, the envisioning of alternative scenarios could initiate a discussion on the next steps and create the partnerships needed for action (Walker et al. 2004). A full understanding of the potential gains and losses of valued ecosystem goods and services as related to each scenario is also critical for scenario evaluation and decision making. The experiential knowledge of the natural resource professionals provided an integrated view of the system; experimental knowledge, e.g., quantitative evaluation of thresholds related to understory competition and the economic expense of oak regeneration, is now needed to identify cause and effect, inform scenario development, and provide access to those seeking action (Fazey et al. 2005).

Overall, our study illuminated key system components and processes, and highlighted potential system uncertainties, namely forest parcelization, housing development, and the spread of invasive diseases, pests, and plants, which can be used to create alternative visions of the future (Peterson et al. 2003b), addressing aspects of the first two steps in the resilience analysis and management approach (Walker et al. 2002). Furthermore, we were able to more fully understand emergent properties in the system, such as landowner forest management behavior, which would not be possible without a systems approach. Our findings also contribute more broadly to discussions of the resilience of disturbancedependent forest types, especially related to broadscale system drivers that require policies and management regimes attuned to appropriate scales of influence. As has been noted in dry ponderosa pine-dominated landscapes in the southwestern $U$. S., conservation planning and restoration are needed at the landscape scale, which can help accommodate the multiple site-level objectives taken in the aggregate (Noss et al. 2006). Similarly in our disturbance-dependent system, there are multiple land use objectives that can conflict with site-level oak management, and thus a targeted approach toward restoring disturbance regimes in ecologically and socially suitable areas is warranted (Knoot et al. 2010). Our study also points to the need for policies and management that address broad-scale constraints while remedying scale mismatches, i.e., managing landscape-level disturbance regimes necessitates cross-boundary coordination and concomitant policy mechanisms that encourage such coordination, lessons that can be applied to other disturbance-dependent systems.

Responses to this article can be read online at: http://www.ecologyandsociety.org/voll5/iss4/art5/responses/

\section{Acknowledgments:}

We wish to thank the research participants for sharing their experiences and insights. Project guidance and helpful review comments were provided by R. Atwell, B. Danielson, N. GrudensSchuck, J. Miller, M. Rickenbach, and two anonymous reviewers. $C$. Eberle, B. Jan, A. MacDonald, K. Smith, and M. Boyd participated in transcribing interviews. We received funding from the USDA Forest Service - Northern Research Station and Iowa State University. T. Knoot was a research fellow with the U.S. EPA - STAR Graduate Fellowship Program. EPA has not officially endorsed this publication and the views expressed herein may not reflect the views of EPA. 


\section{LITERATURE CITED}

Abrams, M. D. 1992. Fire and the development of oak forests. Bioscience 42:346-353.

Abrams, M. D. 2005. Prescribing fire in the eastern oak forests: is time running out? Northern Journal of Applied Forestry 22:190-196.

Albert, D.A. 1995. Regional landscape ecosystems of Michigan, Minnesota, and Wisconsin: a working map and classification. General Technical Report NC-178, U.S. Department of Agriculture, Forest Service, North Central Forest Experiment Station, St. Paul, Minnesota, USA.

Abrams, M. D., and G. J. Nowacki. 1992. Historical variation in fire, oak recruitment, and post-logging accelerated succession in central Pennsylvania. Bulletin of the Torrey Botanical Club 119:19-28.

Allison, H. E., and R. J. Hobbs. 2006. Science and policy in natural resource management: understanding system complexity. Cambridge University Press, Cambridge, UK.

Bliss, J. C. 2000. Public perceptions of clearcutting. Journal of Forestry 98:4-9.

Burns, R. M., and B. H. Honkala, technical coordinators. 1990. Silvics of North America: hardwoods. Agriculture Handbook 654, vol.2. U.S. Department of Agriculture, Forest Service, Washington, D.C., USA

Butler, B. J., and E. C. Leatherberry. 2004. America's family forest owners. Journal of Forestry 102:4-9.

Chapin, F. S., III, T. S. Rupp, A. M. Starfield, L. DeWilde, E. S. Zavaleta, N. Fresco, J. Henkelman, and A. D. McGuire. 2003. Planning for resilience: modeling change in human-fire interactions in the Alaskan boreal forest. Frontiers in Ecology and the Environment 1:255-261.

Checkland, P. B. 1981. Systems thinking, systems practice. John Wiley \& Sons, Chichester, UK.

Cissel, J. H., F. J. Swanson, and P. J. Weisberg. 1999. Landscape management using historical fire regimes: Blue River, Oregon. Ecological Applications 9:1217-1231.
Crow, T. R. 1988. Reproductive mode and mechanisms for self-replacement of northern red oak (Quercus rubra): a review. Forest Science 34:19-40.

Cumming, G. S., D. H. M. Cumming, and C. L. Redman. 2006. Scale mismatches in socialecological systems: causes, consequences, and solutions. Ecology and Society 11(1): 14. [online] URL: http://www.ecologyandsociety.org/vol11/iss1/ art14/.

Delcourt, H. R., and P. A. Delcourt. 1997. PreColumbian Native American use of fire on Southern Appalachian landscapes. Conservation Biology 11:1010-1014.

Drever, C. R., G. Peterson, C. Messier, Y. Bergeron, and M. Flannigan. 2006. Can forest management based on natural disturbance maintain ecological resilience? Canadian Journal of Forest Research 36:2285-2299.

Esterberg, K. G. 2002. Qualitative methods in social research. McGraw-Hill, Boston, Massachusetts, USA.

Fazey, I., J. A. Fazey, and D. M. A. Fazey. 2005. Learning more effectively from experience. Ecology and Society 10(2): 4. [online] URL: http:// www.ecologyandsociety.org/vol10/iss2/art4/.

Fralish, J. S. 2004. The keystone role of oak and hickory in the central hardwood forest. Pages 78-87 in M. A. Spetich, editor. Upland oak ecology symposium: history, current conditions, and sustainability. General Technical Report SRS-73, U.S. Department of Agriculture, Forest Service, Southern Research Station, Asheville, North Carolina, USA.

Fralish, J. S., F. B. Crooks, J. L. Chambers, and F. M. Harty. 1991. Comparison of presettlement, second-growth and old-growth forest on six site types in the Illinois Shawnee Hills. American Midland Naturalist 125:294-309.

Franklin, J. F., T. A. Spies, R. VanPelt, A. B. Carey, D. A. Thornburgh, D. R. Berg, D. B. Lindenmayer, M. E. Harmon, W. S. Keeton, D. C. Shaw, K. Bible, and J. Chen. 2002. Disturbance and structural development of natural forest ecosystems with silvicultural implications, using 
Douglas-fir forests as an example. Forest Ecology and Management 155:399-423.

Gunderson, L. H. 2000. Ecological resilience-in theory and application. Annual Review of Ecology and Systematics 31:425-439.

Gunderson, L. H., and C. S. Holling, editors. 2002. Panarchy: understanding transformations in human and natural systems. Island Press, Washington, D.C., USA.

Gustafson, E. J., R. B. Hammer, V. C. Radeloff, and R. S. Potts. 2005. The relationship between environmental amenities and changing human settlement patterns between 1980 and 2000 in the Midwestern USA. Landscape Ecology 20:773-789.

Hessburg, P. F., J. K. Agee, and J. F. Franklin. 2005. Dry forests and wildland fires of the inland Northwest USA: contrasting the landscape ecology of the pre-settlement and modern eras. Forest Ecology and Management 211:117-139.

Holling, C. S. 1973. Resilience and stability of ecological systems. Annual Review of Ecology and Systematics 4:1-23.

Holling, C. S., and G. K. Meffe. 1996. Command and control and the pathology of natural resource management. Conservation Biology 10:328-337.

Huntsinger, L., L. Buttolph, and P. Hopkinson. 1997. Ownership and management changes on California hardwood rangelands: 1985 to 1992. Journal of Range Management 50:423-430.

Iowa Department of Natural Resources. 2005. Forest stewardship spatial analysis project. [online] URL: http://www.fs.fed.us/na/sap/products/ia.shtml

Ison, R. L., P. T. Maiteny, and S. Carr. 1997. Systems methodologies for sustainable natural resources research and development. Agricultural Systems 55:257-272.

Jacobs, R. D., and R. D. Wray. 1992. Managing oak in the Driftless Area. Publication number BU-05900. Minnesota Extension Service, University of Minnesota, St. Paul, Minnesota, USA.

Johnson, P. S., S. R. Shifley, and R. Rogers. 2002. The ecology and silviculture of oaks. CABI Publishing, New York, New York, USA.
Kittredge, D. B. 2005. The cooperation of private forest owners on scales larger than one individual property: international examples and potential application in the United States. Forest Policy and Economics 7:671-688.

Kittredge, D. B., Jr., A. O. Finley, and D. R. Foster. 2003. Timber harvesting as ongoing disturbance in a landscape of diverse ownership. Forest Ecology and Management 180:425-442.

Knoot, T. G. 2008. The state, resilience, and potential future of oak-dominated forests in the Driftless Area of the midwestern U.S. Dissertation. Iowa State University, Ames, Iowa, USA.

Knoot, T. G., L. A. Schulte, N. Grudens-Schuck, and M. Rickenbach. 2009. The changing social landscape in the Midwest: a boon for forestry and bust for oak? Journal of Forestry 107:260-266.

Knoot, T. G., L. A. Schulte, and M. Rickenbach. 2010. Oak conservation and restoration on private forestlands: negotiating a social-ecological landscape. Environmental Management 45:155-164.

Kromroy, K., K. Ward, P. Castillo, and J. Juzwik. 2007. Relationships between urbanization and the oak resource of the Minneapolis/St. Paul Metropolitan area from 1991 to 1998. Landscape and Urban Planning 80:375-385.

McShea, W. J., and W. M. Healy. 2002. Oaks and acorns as a foundation for ecosystem management. Pages 1-9 in W. J. McShea and W. M. Healy, editors. Oak forest ecosystems: ecology and management for wildlife. The Johns Hopkins University Press, Baltimore, Maryland, USA.

Meekins, J. F., and B. C. McCarthy. 1999. Competitive ability of Alliaria petiolata (Garlic mustard, Brassicaceae), an invasive, nonindigenous forest herb. International Journal of Plant Sciences. 160:743-752.

Meekins, J. F., and B. C. McCarthy. 2001. Effect of environmental variation on the invasive success of a nonindigenous forest herb. Ecological Applications 11:1336-1348.

Noss, R. F., P. Beier, W. W. Covington, R. E. Grumbine, D. B. Lindenmayer, J. W. Prather, F. Schmiegelow, T. D. Sisk, and D. J. Vosick. 2006. Recommendations for integrating restoration 
ecology and conservation biology in ponderosa pine forests of the southwestern United States. Restoration Ecology 14:4-10.

Nowacki, G. J., and M. D. Abrams. 2008. The demise of fire and "mesophication" of forests in the eastern United States. Bioscience 58:123-138.

Palik, B. J., R. J. Mitchell, and J. K. Hiers. 2002. Modeling silviculture after natural disturbance to sustain biodiversity in the longleaf pine (Pinus palustris) ecosystem: balancing complexity and implementation. Forest Ecology and Management 155:347-356.

Palik, B. J., and K. S. Pregitzer. 1992. A comparison of presettlement and present-day forests on two bigtooth aspen-dominated landscapes in Northern Lower Michigan. American Midland Naturalist 127:327-338.

Patton M. Q. 2002. Qualitative research and evaluation methods. Sage Publications, Thousand Oaks, California, USA.

Peterson, G. D., G. S. Cumming, and S. R. Carpenter. 2003a. Scenario planning: a tool for conservation in an uncertain world. Conservation Biology 17:358-366.

Peterson, G. D., T. D. Beard, Jr., B. E. Beisner, E. M. Bennett, S. R. Carpenter, G. S. Cumming, C. S. Dent, and T. D. Havlicek. 2003b. Assessing future ecosystem services: a case study of the Northern Highlands Lake District, Wisconsin. Conservation Ecology 7(3): 1. [online] URL: http:/ /www.consecol.org/vol7/iss3/art1.

Platt, W. J., G. W. Evans, and S. L. Rathbun. 1988. The population dynamics of a long-lived conifer (Pinus palustris). The American Naturalist 131:491-525.

Povak, N. A., C. G. Lorimer, and R. P. Guries. 2008. Altering successional trends in oak forests: 19 year experimental results of low- and moderateintensity silvicultural treatments. Canadian Journal of Forest Research 38:2880-2895.

Prasad, A. M., L. R. Iverson, S. Matthews, M. Peters. 2007. Climate change tree atlas: a spatial database of 134 tree species of the eastern USA. Northern Research Station, U.S. Department of
Agriculture, Forest Service, Delaware, Ohio, USA. [online] URL: http://www.nrs.fs.fed.us/atlas/tree.

Prior, J. C. 1991. Landforms of Iowa. University of Iowa Press, Iowa City, Iowa, USA.

Pusateri, W. P., D. M. Roosa, and D. R. Farrar. 1993. Habitat and distribution of plants special to Iowa's Driftless Area. Journal of the Iowa Academy of Sciences 100:29-53.

QSR International. 2006. NVivo 7. QSR International, Victoria, Australia.

Radeloff, V. C., D. J. Mladenoff, and M. S. Boyce. 2000. A historical perspective and future outlook on landscape scale restoration in the northwest Wisconsin Pine Barrens. Restoration Ecology 8:119-126.

Radeloff, V. C., R. B. Hammer, and S. I. Stewart. 2005. Rural and suburban sprawl in the U.S. Midwest from 1940 to 2000 and its relation to forest fragmentation. Conservation Biology 19:793-805.

Rickenbach, M., K. Zeuli, and E.Sturgess-Cleek. 2005. Despite failure: the emergence of "new" forest owners in private forest policy in Wisconsin, USA. Scandinavian Journal of Forest Research 20:503-513.

Rodewald A. D., and M. D. Abrams. 2002. Floristics and avian community structure: implications for regional changes in eastern forest composition. Forest Science 48:267-272.

Rogers, E. M. 2003. Diffusion of innovations. Fifth edition. Free Press, New York, New York, USA.

Rooney, T. P., and D. M. Waller. 2003. Direct and indirect effects of white-tailed deer in forest ecosystems. Forest Ecology and Management 181:165-176.

Schulte, L. A., D. J. Mladenoff, T. R. Crow, L. C. Merrick, and D. T. Cleland. 2007. Homogenization of northern U.S. Great Lakes forests due to land use. Landscape Ecology 22:1089-1103.

Seastedt, T. R., R. J. Hobbs, and K. N. Suding. 2008. Management of novel ecosystems: are novel approaches required? Frontiers in Ecology and the Environment 6:547-553. 
Strauss, A., and J. Corbin. 1990. Basics of qualitative research: grounded theory procedures and techniques. Sage Publications, Newbury Park, California, USA.

Suding, K. N., K. L. Gross, and G. R. Houseman. 2004. Alternative states and positive feedbacks in restoration ecology. Trends in Ecology and Evolution 19:46-53.

Trimble, S. W., and P. Crosson. 2000. U.S. soil erosion rates-myth and reality. Science 289:248-250.

US Forest Service. 2010. Forest inventory and analysis DataMart, version 4.0. [online] URL: http ://199.128.173.17/fiadb4-downloads/datamart.html

Walker, B., S. R. Carpenter, J. Anderies, N. Abel, G. S. Cumming, M. Janssen, L. Lebel, J. Norberg, G. D. Peterson, and R. Pritchard. 2002. Resilience management in social-ecological systems: a working hypothesis for a participatory approach. Conservation Ecology 6(1): 14. [online] URL: http://www.consecol.org/vol6/iss 1/art14.

Walker, B., C. S. Holling, S. R. Carpenter, and A. Kinzig. 2004. Resilience, adaptability, and transformability in social-ecological systems. Ecology and Society 9(2): 5. [online] URL: http://w ww.ecologyandsociety.org/vol9/iss2/art5.

West P. C., J. M. Fly, D. J. Blahna, and E. M. Carpenter. 1988. The communication and diffusion of NIPF management strategies. Northern Journal of Applied Forestry 5:265-270.

Wisconsin Department of Natural Resources. 2005. Wisconsin's strategy for wildlife species of greatest conservation need. Pub-ER-641, Madison, Wisconsin, USA. 
APPENDIX 1. Example interview questions, including potential probing questions to further clarify interviewees' responses.

\section{Interview Question}

What is your role as a natural resources professional?

What kinds of changes have you seen to the forest resources in your region?

What are your main concerns about the forest resources in your region?

In your experience with private landowners, what concerns do landowners have about their forests?

What do you think are the main threats to oak regeneration in your region?

What impact do you think invasive plants and shrubs have on forests in your region?

What would you prefer the forests to look like in 50 to 100 years?

\section{Probing / Clarifying Question}

- How long have you been in this profession?

- In what area of the study region do you work?

- What kinds of changes have occurred to the forested landscape / within forest stands / oak forests / privately owned forests?

- What are your main concerns about oak forests in your region?

- What are your concerns regarding state-owned land / privatelyowned forests?

- What kinds of interactions do you have with private landowners?

- For what reasons do private landowners seek your advice?

- What types of management recommendations are made to address these threats?

- Do we have enough information to address the threats to oak regeneration, and if not, what is needed?

- What invasive plants and shrubs are important in your region?

- What types of management recommendations are made to combat invasive plants and shrubs?

- What would you prefer the oak forests to look like in 50 to 100 years?

- How can we realize this vision? 
APPENDIX 2. Examples of some of the main components, processes, thresholds, and uncertainties of the oak social-ecological system, as described by regional natural resource professionals. These system features are categorized as either ecological or social/economic in nature and vary in the scale at which management and/or policy mechanisms are or could be used to address them. Example quotations are given to illustrate each feature (pseudonyms are used to protect interviewees' identities).

\section{Key System Component or Process}

Deer herbivory $^{1} \quad$ Ecological

Spread of invasive Ecological oak pests and diseases $^{1,2}$

\section{Type of Management/ Example Quotation Issue Policy Scale}

Site-level, multi-parcel, and regional

[Deer herbivory] has gone ballistic. . . There are a lot of woods that you can't find any tree younger than 20 years of age. And there are just browse lines on the edge of the woods. Talk about an oak regeneration problem! That's an enormous problem for Northeast Iowa. It's the number one culprit; I'm 100\% convinced of that. It's not just shade and succession. . . . The bottom line is, let's say if you look at the deer pressure on a scale of 1 to 10; 10 being the worst. Well, you could probably just plant seedling walnut, cherry, ash, and spruce; if it was like a 7 or an 8, you could get by with certain things. But we're going to have to get that herd down to a 4 to grow oak again. To really be able to grow oak consistently, because [the deer are] selectively browsing [oak]. - Tim, a public forester for over 10 years

Site-level, My main concern right now is what's on the horizon with gypsy moth and multi-parcel, regional, national, and global

emerald ash borer coming at us. I think that too is going to change the face of the Driftless Area. Gypsy moth is going to rage through; it's going to take — probably the first go-around-it's going to take all the unhealthy trees, trees on poor aspects. Between that and black oak, our south slope red oak stands could be decimated. The oak wilt is going to get them, or gypsy moth is going to defoliate them three years in a row. - Bob, a veneer buyer in the region for nearly 20 years

Site-level, Now the number one problem we've got ... is the invasive species. multi-parcel, European buckthorn has completely changed what we're doing either for regional, post-treatment or follow-up treatment. It's the primary thing we have to kill. national, and It gets so bad there even sugar maple can't regenerate. And it's incredibly global expensive. - Leo, a consulting forester for over 20 years
Advanced sugar Ecological maple regeneration ${ }^{1}$

Landowner adoption of oak management practices
Social/ Economic
Site-level, multi-parcel, regional
And with red oak, with this amount of deer herd that we have, and with the amount of competition that's generated, it's next to impossible to get red oak to regenerate in this hardwood stand. Unless you do very intensive management. And then what's the point if you've already got basswood and maple encroaching. You can manage until you're blue in the face and it's still going to encroach! - Leo, a consulting forester for over 20 years

Site-level, multi-parcel, regional
A lot of landowners when they write their [management plans] . . they'll say, 'I want to manage for oak.' Well, when you talk to them and you find out about it, they really mean, 'I don't really want to manage for oak, I don't want to manage another oak stand, but I really like the oak trees I have. So I really want to keep these oak trees.' But they're not willing to go through the expense, and the time, and the effort to actually try to bring back oak.

-Dan, a consulting forester for nearly 10 years 
Site-level economic cost of oak regeneration
Social/

Economic
Site-level

Social/

Economic

parcelization and

exurban housing

development $^{1,2}$

Short-term

Social/

aesthetic appeal of Economic property
Site-level, multi-parcel, regional, and national
Site-level
In these direct [oak] seedings, we usually get really good germination of your oaks, red and bur anyway, but the deer usually get them, or the rabbits. What they've gone to doing is basically leaving out the acorn component and... going in the following spring and planting 10-20 good sized oak and then caging them, a wire cage. Although it's a lot of work and it gets spendy, it might be the way we'll have to go to guarantee oak until the deer herd is thinned out. . . But that costs almost $\$ 10$ a tree.

—Dale, a logger and contract forester for over 30 years

The other change is that the forest is being fragmented. . . . Because the value of recreational land right now, it's worth more than crop land. People are paying \$3,000 dollars an acre for a place to hunt. People are selling off that woods from the farm, and it's fragmenting the landscape. - Grant, a public forester for nearly 30 years

During the harvest, it's going to be ugly, no doubt. For ten years after the harvest, even if you do everything right, it's going to be so thick you can't walk through it. So it's not real enjoyable. And then after 15 or 20 years it starts to kind of become a little easier to get through. - Rich, a consulting forester for nearly 20 years

Site-level I see a lot of building going on out in the timber and I hate to see that too. I think that takes away from the timber resource. . . . They want some recreation ground. They want a park. . . They've got resources available, financial resources they can actually build a house and [they think], 'Look, this is great, we can live out in the park.' Parks are not managed for timber very well, they're there for looks; they're not there for timber management that usually involves some sort of cutting, disturbances we're talking about. And people that live out there, well they don't want to disturb it...They don't want to mess it up. That's makes it tough to do some sort of management activity. - Todd, a consulting forester for over 10 years

Social/ Economic

Landowner posting "no hunting" of property

Stumpage price of sugar maple $>=$ oak
Social/ Economic

Regional, national, and global
Site-level, multi-parcel, regional

A recreational buyer . . . the first thing they do is slap "no hunting" signs all over their boundaries. . . . One of my clients . . . he lived there most of his life and... he said when he was a kid he could count 23 different farms in this area that he could hunt. And he says now there's only one farm of those 23 he's got any permission to hunt on, and all the others have been locked up. - Tim, a public forester for over 10 years

But since there was a lot of over mature [oak] timber, a lot of these woods had maple-basswood understory. When you finally took the bigger oak, it released the maple-basswood, so now we've got some more pure stands of maple-basswood. Which, in our industry, the way we're looking at it now with hard maple being excellent, even more valuable than oak, and basswood kind of a medium grade value wood, we're going to manage for those timbers.

-Paul, a sawmill owner for over 25 years

Social/ Economic
Regional, national
Say you have 30 contiguous acres of woods and if it is owned by one property owner, say it's a nice red oak stand for the most part. If that one landowner. . . he would be much more apt to be able to carry out proper silviculture on it, carry out a harvest on it, regenerate the oak. That same 30 acre parcel is now six landowners of five acres apiece. The likelihood of being able to get that harvested in the same way is gonna be a lot more difficult, because... you have six different landowners and...for them all to have the same interest and same goals, both short-and long-term, is not always the case. . . It kind of takes away some of the managing based on what the actual resources are. It takes away some tools from sound forest management. . . . It brings more social or human factors into...[how] the actual management is carried out on that property. —Sam, nearly 10 years as a public forester 
Landowner contact Social/ with natural Economic resource professional
Site-level, regional

Probably the biggest challenge with the landowners is getting them to call. Once, if they call, then the chances of them doing something are pretty high. Once you start working with them, most people, when they see what needs to be done in their woods, everybody's willing to do something. The costsharing is a big benefit in that.... The cost of doing this stuff, if it gets too prohibitive, it's going to prevent people from [managing their forest]. -Rob, a public forester for over 15 years

\section{Social/} Economic
Site-level, regional, national
A lot of the harvesting that occurs...is at the whim of the owner and the logger. And what typically happens still is a high-grade down to a certain [tree] diameter limit, and in a lot of cases that just tends to promote further conversion to, if we're lucky here, maybe northern hardwoods-sugar maple, basswood, ash-or if you're unlucky, it's elm, hickory and box elder. So we have a wholesale conversion of former oak stands to something else. -Jake, a public forester for over 30 years

${ }^{1}$ Described as a key system threshold; once a critical level is reached, management practices are ineffective or cost prohibitive.

${ }^{2}$ Described as a critical uncertainty in the system. Natural resource professionals were uncertain about the future trajectory of these components or processes or unsure about how or if management and policy mechanisms could be implemented to address these issues 